\title{
Kamusal Alanın Oluşumu ve Değișen Görsel Kültür Bağlamında İngiltere ve Fransa'da Süreli Yayınların Doğuşu
}

\author{
Sevgi Arı \\ Çukurova Üniversitesi Eğitim Fakültesi Güzel Sanatlar Eğitimi Bölümü Grafik Ana Sanat Alanı, Balcalı / ADANA ORCID ID: 0000-0001-6153-3714
}

\begin{abstract}
Özet
Önem: Bilgiyi kayıt altında tutma motivasyonundan güç alan yazı, bu bilgilerin sonraki kuşaklara taşınması noktasına önemli bir rol üstlenmiş, fakat yazı yüzeylerinin bağlayıcılı̆̆ı nedeniyle uzunca bir zaman yer değiștirebilecek nitelikte olmamıștır. Taşınabilir yazı yüzeylerinin oluşması, süreli yayınların tarihteki doğuşunu da mümkün kılmışıır.

Amaç: İnsanlığın ilk haberleșme ihtiyaçlarından başlayıp, yayın türlerinin oluşumuna dek geçen süreci içeren bu çalışmada süreli yayınlar bir kitlesel iletişim aracı olarak ele alınmıștır. Bu nedenle süreli yayınlar, tașıdıkları tasarım değerlerinin yanı sıra tarihteki toplumsal kııılma noktalarında taşıdıkları roller üzerinden de konu edilmiștir. Yöntem: Süreli yayınların sahip oldukları çok boyutlu nitelikleri, çalışmanın içeriğine de yansımıştır. Çalışmanın örnekleri süreli yayınların kimlik kazanmasında öne çıkan adımların atıldığı İngiltere ve Fransa’dan seçilmiștir. Sonuç: Bu çalışmada, süreli yayınların insanın en temel ihtiyacı olan haberleşme ihtiyacından doğduğu ve tarihsel süreçte hem teknik hem de toplumsal dönüşümlerden bağımsız değerlendirilemeyeceği sonucu çıkmıștır. Dolayısıyla birer grafik ürün olan süreli yayınlar, çağlar içerisinde değișen, dönüșen ideolojilerin ve kitlesel iletişim pratiklerinin yansımalarıdır.
\end{abstract}

Anahtar kelimeler: Süreli Yayın, Gazete, Dergi, Kitlesel iletişim, Kamusal alan, Basın, Basın özgürlüğü

\section{The Emergence of the Periodicals in England and France in the Context of Public Space and Changing Visual Culture}

\begin{abstract}
Importance: The scripts, which was motivated by recording the information, had played an important role in information transfer to next generations, but it had not been to possible to move them for a long time due to the heavy writing surfaces. The formation of portable writing surfaces has also made the emergence of the periodicals possible in history.

Aim: In this study, which includes the process from the first communication needs of the humankind to the formation of different types of publications, periodicals are considered as a mass communication tools. For this aim, periodicals are also discussed in terms of the design values they carry, as well as their roles in social break points in history.

Method: Multidimensional qualifications of periodicals are reflected in the content of the study. The examples of the study were selected from the steps taken in England and France for the periodicals to gain identity.

Conclusion: It is concluded that periodicals are born from the need of communication, which is the most basic need of humankind and cannot be evaluated independently from both technical and social transformations in history. Therefore, periodicals as graphical products are the reflections of ideologies and mass communication practices that have changed and transformed over the ages.
\end{abstract}

Keywords: Periodicals, Newspapers, Magazines, Mass communication,Public Space, Press, Freedom of the Press

\section{Giriș}

İnsanın bilgiyi yayma (haberleşme) arzusu, yazının olmadığı tarih öncesi çağlardan beri mevcuttur. Ağaçların, dalların, taşların; yani doğada hali hazırda

*Yazışma Adresi / Address for Correspondence:

Sevgi Arı, Email: sevgiarigrf@gmail.com

Geliş Tarihi / Received Date: 14.11.2018

Kabul Tarihi / Accepted Date: 03.12.2018

Doi: $10.26701 /$ uad. 482707 var olan nesnelerin kullanımına dayanan ilk haberleşme etkinlikleri, zaman içerisinde farklı kabilelerin kabul etmesiyle ortak bir anlaşma aracına dönüşmüştür (Saxby, 1990: 42). Ağaçlara atılan çentikler, kırılmış dallar, renkli çakıl taşları, düğümlenmiş ipler, gündüzleri dumanlar veya geceleri yakılan ateşler henüz yerleşik hayata geçmemiş küçük gruplar arasındaki haberleşme ağıdır. Bu gösterge dili ile kimi zaman düşmanın yaklaştığını, kimi zaman da bir av hayvanının yakınlarda olduğunu birbirlerine anlatmışlardır. Kızıl derililerin savaș açmak iste- 
diklerinde diğer kabileye bir mızrak veya ok; barıș zamanında ise tütün ve çubuk gönderdiği bilinmektedir.

Toplumların yazıya geçiş sürecinde sözel aktarımlar önemli bir işlev görmüş ve farklı coğrafyalar arasındaki bilgi aktarımında hissedilen boşluk, ulaklar tarafından doldurulmuştur. Bu kişiler günümüzdeki hafıza kartlarıyla benzer şekilde hafızalarında tuttukları mesajları bir yerden diğerine taşımıștır. M.Ö. 490 yılında, Yunanlıların Perslere karşı kazandıkları zaferi haber vermek için Atina'ya kadar kilometrelerce koşan habercinin orada ülkesinin zaferini anlattıktan sonra bitkinlikten öldüğü, ne yazık ki kayıtlara geçmiştir (Jeanneney, 2006: 21).

Haberleşme ihtiyaçlarının bu ilk örneklerinin, savaş veya zaferlerin, ölüm ya da yaşamın, tehdit veya barış seçeneklerinin hüküm sürdüğü bir dönemi yansıttığını söylemek mümkündür. Söz konusu savaş ve barış dünyasında geçmişten bugüne haberleşme etkinlikleri hayati bir ihtiyaç olma rolünü hiç bir zaman kaybetmemiştir. Diktatörlerin egemenliğini sürdürmesinde bir propaganda aracı olarak kullandıkları haber mekanizmaları, toplumların demokratikleşmesi süreçlerinde de önemli roller oynamıştır. Haberleşme etkinlikleri ile toplumsal dönüşümler arasındaki diyalektik ilişkinin izlerinin sürüldüğü bu araştırmanın ilerleyen bölümlerinde süreli yayınlar, kamusal bilincin oluşumuyla ve tekniğin evrimiyle olan ilişkisi dâhilinde incelenmektedir.

\section{TEKNIĞIN ETKISIYLE DÖNÜŞEN SÜRELI YAYINLAR}

Eski Yunan'da ilkçağdan beri, panayır, agora, forum veya tapınak gibi halkın topluca bulunduğu yerlerin haberleşme amaçlı kullanıldığı bilinmektedir. M.Ö 50’li yıllarda Julius Caesar'ın Romalı vatandaşların okuması üzerine duvarlara astırdığı “Acta Senatus”ları bir tür resmi gazete olarak adlandırmak mümkündür. Bu resmi yayınlara cevaben halkın yayınladığı karşı bültenler "Acta Publica" adını almıştır. Benzer şekilde "Acta Duirna" adı verilen bültenler; cenaze törenleri, yangınlar, iflaslar, idamlar, spor oyunları vb. toplumu bilgilendirme amacıyla aynı dönem içerisinde kullanılmıştır (Martin, 1981: 201).

Devletlerin ulaklarla haberleşme alışkanlığı İran'da Perslerin öncülüğünde M.Ö. 7. yüzyılda kurulan posta merkezi ile yerini yazılı metne devretmiş, Hindistan, Çin, Roma gibi uygarlıklar da bu uygulamayı takip etmiştir (Wright, 2016: 135). Geniş coğrafyalara yayılmaya başlayan uygarlıklar, sahip oldukları topraklarla aralarındaki haberleşmeyi el yazması mektuplar (ing.newsletter)la sürdürmüştür. Süreli yayınların atası olan bu el yazması mektuplar, devletlerin bilgi ăğ'nın da temelini oluşturmuş; kimi zaman manipülatif amaçlarla da kullanılmıştır. Günümüz süreli yayınlarında da bolca karşılaştığımız görsel kullanımının ilk örnekleri bu bültenlerde başlamış, kimi zaman savaş sahneleri ya da kralın zaferi gibi görsellerin eklenmesiyle haberin daha etkili hale gelmesi hedeflenmiştir. Tarihte kayıtlara geçmiş ilk yalan haber ise
Ortaçağ'dan çok daha eskilere, Antik Mısır dönemine dayanmıştır. M.Ö. 1275 yılında Hititler ile Mısırlılar arasında geçen Kadeş Savaşı'nı her iki ülkenin liderinin büyük bir zafer olarak halkıyla paylaştığı, ama bu savaşın gerçekte her iki taraf için de yarı-yenilgi pozisyonunda sonuçlandığı bilinmektedir (Ham, 2011: 252).

Yazının taşınabilir ve çoğaltılabilir hale gelmesi noktasındaki ilk önemli teknik gelişme papirüs ve parşömenlerin üretilmesi olmuştur. Nil Deltası'nın coğrafi koşulları gereği o bölgede bolca olan kamışların çeşitli işlemlerden geçmesiyle üretilen papirüsler, Eski Mısır'da el yazması metinlerdeki artışı sağlarken; ağırlığı azaltmasıyla da bir değişimi tetiklemiştir. Anıtsal taş yüzeylerde hiyeroglifleri kullanan Misırlılar, daha hızlı yazma hedefiyle papirüs yüzeylerde işlek yazı da denilen "demotik" yazıyı bu sayede geliştirmişlerdir. Kendi coğrafi sınırları içerisinde yazının taşınabilir bir varlığa dönüşmesi adına pratik bir çözüm olan papirüsler, uzak ülkelere gemilerle rulolar halinde taşınırken zamana ve mesafelere dayanıklı olma noktasında naif kalmışlardır. Bergama bölgesinde hayvan derisinden üretilmeye başlanan parşömenler ise ahşap baskı tekniğinin kullanım şekli nedeniyle yaygınlık kazanamamıştır. Büyük tahta bloklarla üzerine baskılar yapılan parşömenler, büyük kodekslere dönüşmüş; dayanıklı olmalarına rağmen uzak coğrafyalara taşınmaları noktasında hantal kalmışlardır. ${ }^{1}$

İpek Yolu üzerinden öncelikle Semerkand, Bağdad, Mekke gibi şehirlere Çin'den taşınan kağıt üretim tekniği, M.S.1102 civarlarında da Araplar tarafından İspanya'ya aktarılmıştır. ${ }^{2}$ Sicilya'da üretilen ilk kağıdın Avrupa'nın geneline yayılması ise 100 yılı aşkın bir zaman almıştır. Bu aktarım sürecinde Avrupa'da kağıdın ham maddesi olarak eskimiş elbiseler, döşemelik kumaşlar, perdeler ve paçavralar kullanılmıştır. Uzak Doğu'nun kadim bilgilerinin Avrupa coğrafyasına yayılmasında gezginlerin gözlemlerini paylaştığı kitapların bir çok dile çevrilmesinin de etkisi olduğu bilinmektedir. Örneğin 1298 yılında yakalanarak Genoa'da tutuklanan Venedikli gezgin Marco Polo, gittiği yerlerde gördüklerini diğer bir tutuklu olan Rustichello'ya anlatmış ve bu anlatılardan, ortaya "Marco Polo'nun Seyahatleri” isimli kitap çıkmıştır. Bu kitapta Marco Polo, İpek Yolu'na ve Çin Seddi'ne dair gözlemlerini aktarmış ve Çin'deki kağıda, kağıt paraya ve bunların nasıl üretildiğine dair detaylı bilgilere yer vermiştir (Burger, 2007: 29)

Avrupa'da kitlesel iletişimi, yazının mekanik çoğaltımı bağlamında mümkün kılan en büyük teknik gelişme ise bilindiği gibi matbaanın 1470'li yıllarda Almanya'nın Mainz kentinde kullanıma girmesi olmuştur. ${ }^{3}$ Avrupa coğ-

\footnotetext{
1 Parşömen, Mısır Hükümdarı Epiphane'in papirüs ihracını yasaklaması sonu cunda M.Ö. 190'da bu yokluğa bir alternatif olarak üretilmeye başlanmıştır. O zamanki adıyla Pergamon'un kralı olan II. Eumenes'in parşömen üretimi sayesinde hükümdar olduğu topraklarda bir kütüphane kurduğu bilinmektedir. (Deibert, 1997: 55).

${ }^{2}$ Haberleşme ağının çok eskilere dayandığı Uzakdoğu'da MS.911 yılında Çin'de "King Pao" adlı bir gazetenin yayınlanmaya bașladığı ve uzun yıllar yayınına devam ettiği bilinmektedir (Ertuğ, 1970: 19).

${ }^{3}$ Matbaanın bulunduğu yıllara dek Italya Avrupa'daki belli başlı kağıt üretim merkezi olmuştur.
} 
rafyasına hızla yayılan matbaa tekniği, kitlesel iletișim etkinliklerinin çehresini hem içerik hem de görsel kimlik bağlamında kökten değiştirmiştir. Bu dönemde çeşitli felsefi metinler farklı dillere çevrilerek çok daha hızlı bir şekilde çoğaltılmaya başlanmış, aktarımdaki bu hızlanma bilginin otoritelerin tekelinden çıkmaya başlaması anlamına gelmiştir. Matbaa ile birlikte sınırlı sayıda ve pahalı olan el yazması haberler ucuzlamış, basılı ürünler halk tarafından da satın alınabilir olmuş / yaygınlaşmıştır. ${ }^{4}$ Matbaa öncesi bültenlerde yazıcılar, Almanya ve İtalya gibi merkezlere ait ilgi çekici ekonomik ve politik bilgileri; kimi ticari, sanatsal veya dini olayları el yazısı ile kayıt altına almışlardır. Coğrafyalar arasında geçiş yaparken farklı yazıcılar tarafından uç uca eklenen yeni bilgilerle 100, 200, 300 nüsha halinde çoğaltılan ve farklı dillere çevrilen bu yayınlar tiyatro oyunlarından tıbbi haberlere dek farklı konuları da içeriğinde barındırmıştır (Emden, Midgley, 2002: 129).

Matbaa ile birlikte gelişme gösteren ilk basılı süreli yayınlar, düzensiz aralıklarla basılıp-yayımlanmışlardır. Fransa'da "Feuilles Occasionelles" (Tür. ara sıra yayınlanan sayfalar) adını alan ve eleștirel yazılar da içeren bu ilk basılı haberler, el ilanı boyutundaki küçük sayfalardan oluşan 8 ila 16 sayfalık fasiküllerden meydana gelmiştir. 1529 yllından itibaren yine Fransa'da yayınlanmaya başlayan ve Türkçe'de "ördek" anlamına gelen "Canard"lar ise popüler nitelikli haberleri barındırmıștır. "Canard”larda çoğunlukla sel felaketleri, deprem, su baskınları gibi doğa olayları; hayal gücüne dayanan garip cinayetler ya da hayalet öyküleri konu edilmiştir (Murphy, 2016: 68). Dönemin sansasyon basını olan bu ana akım medya kültürünü de şekillendiren "Canard" ların devamında boyutları itibariyle el ve duvar ilanlarına yakın duran magazin içerikli ve Türkçe'de "şarkı" anlamına gelen “chanson”lar ortaya çıkmıştır.

Bu şekilde süreli yayınların günümüzde de geçerli olan: haber içerikli, magazinel ve kültürel içerikli üç türü 16 . yüzyılın sonlarına doğru ayrışmaya, belirginleşmeye başlamıştır. ${ }^{5}$ Şehirlerarası posta servislerinin yanı sıra matbaa basım tekniğinin yaygınlaşmasının da etkisiyle yayın perdiyodları sıklaşan bültenler 16. yüzyılın başlarından itibaren günümüzdekine yakın nitelikler taşımaya başlamıș olsa da gerçek anlamda 'süreli yayın' diyebileceğimiz periyodik yayınların oluşması için 17. yüzyılı beklemek gerekmiştir.

\section{17. YÜZYILDA GELIŞEN BASIN KAVRAMI}

Avrupa'da 17. yüzyıl, günümüzdeki basın kavramının doğduğu; yayın türlerinin, içeriklerin ve kimliklerinin netlik kazandığı, haberciliğin bir meslek dalına dönüştüğü bir yüzyll olmuştur.

\footnotetext{
${ }^{4}$ Avrupa'da süreli yayınlara verilen terimsel isimler "haber ve haberci" kelime köklerinden gelmiş ve bu basılı ürünler İtalya'da "Avvisi", Almanya'da "Zeytungen", İngiltere'de "Corante" adlarını almışlardır (Brownlees, 2011: 26).

${ }^{5}$ Fransızca'da 'nadiren' anlamına gelen “Occasionnel”|er, Italya'da 'bozuk para' anlamına gelen "gazzetta" sözcügünden türetilerek "Gazzette" adını almışlardır.
}

Avrupa'da haftalık olarak yayınlanan ilk basılı iki gazete, Almanya'da birbirlerine çok yakın zamanlarda çıkarılmaya başlanmıştır. Bunlar 1605'te Strasbourg'da yayın hayatına başlayan "Relation" gazetesi ve 1609'da Wolfenbüttel'de yayınlanmaya başlayan "Avisa Relation oder Zeitung" dur (Resim 1). "Relation", yayıncisı Johan Carolus tarafından "tüm öne çıkan ve hatırlanması gereken haberlerin bir dökümü" (Orj. Relation aller Fürnemmen und gedenckwürdigen Historien) olarak tanımlanmıştır. Lucas Schulte tarafindan basılan "Avisa" ise 1632 yilına dek yayınlanmaya devam etmesiyle basin tarihinde önemli bir yer almıştır (Resim 2). Dünya Gazeteciler Birliği tarafından süreklilik ve içerik bakımından değerlendirilerek Avrupa'nın ilk gazeteleri olma ünvanını alan bu gazeteler, tasarım açısından ise günümüz gazete biçeminden henüz çok uzak olmuştur. Daha çok kitap formatına yakın duran bu yayınları Stanley Morisson gazeteden ayrıştırarak "haber kitapları" (Orj. newsbooks) olarak nitelendirmiştir. Nitekim bu yayınlar hem boyut olarak kitap ölçülerinde basılmış ve hem de sayfa tasarımı henüz sütunların değil uzun satırların kullanıldığı bir yerleștirme düzeni ile oluşturulmuştur.

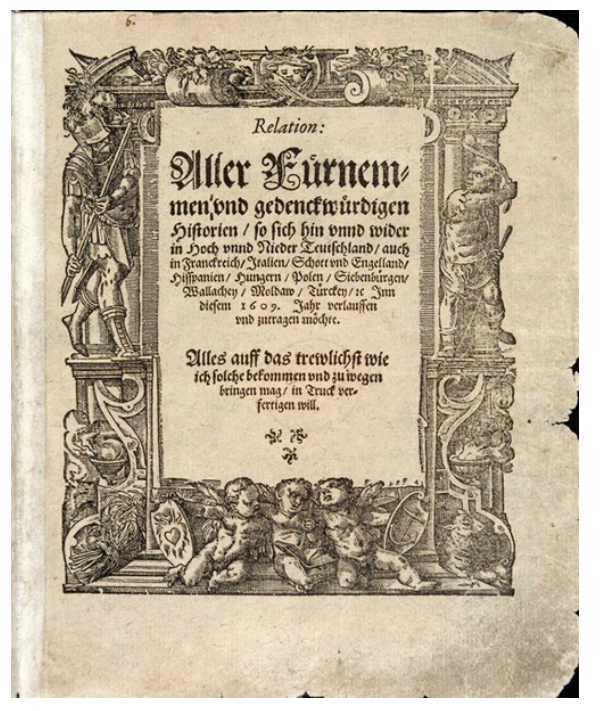

Resim 1: "Relation" başlık sayfası, 1609

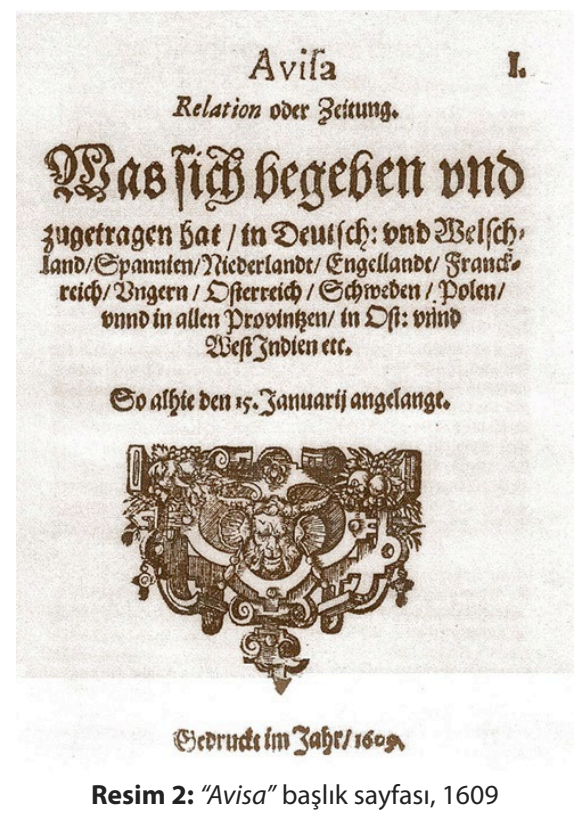




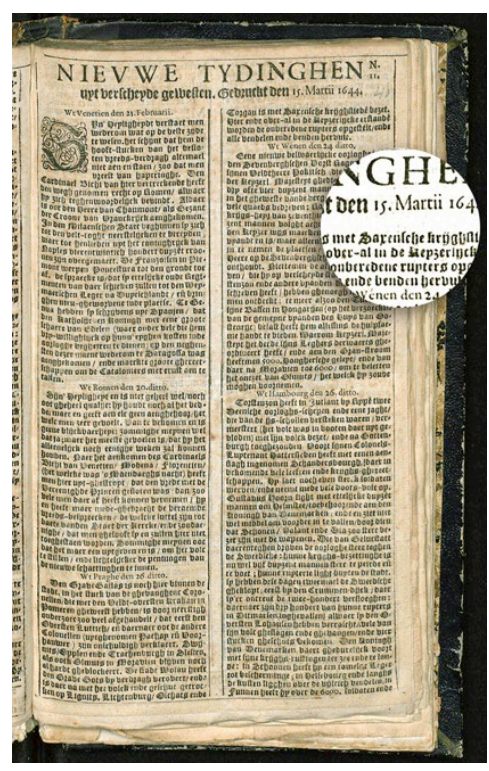

Resim 3: "Nieuwe Tydinghen" iç sayfa, 1644

Haftalık olarak yayınlanan süreli yayınların diğer örnekleri Hollanda'nın Anvers kentinde -önceleri düzensiz aralıklarla yayınlanan- 1605 tarihli "Nieuwe Tydinghen" olmuştur (Resim 3). İsviçre'de ilk haftalık gazete 1610 yılında, Londra'da 1622'de; Paris'te ise 1631'de yayınlanmaya başlanmıştır. Diğer ülkelerde haftada bir yayınlanan ilk gazetelere baktığımızda tarih sırasıyla İtalya'da 1636 'da, Almanya'da 1660 'da, İspanya'da 1661 'de, Kopenhag'da ise 1663 'te yayınlandıklarını görürüz. Bu yayınlarda ortak nokta olarak gotik yazı karakterinin başat olarak kullanılması dikkati çekmektedir. Buna gotik yazının geçmişten gelen kullanımıyla okuyucuda "okuma" edimini karşılayan bir kimliği olmasının neden olduğunu söylemek mümkündür. Tirnaklı yazı karakterleri farklı olmaları nedeniyle çoğunlukla başlıklarda ya da künye bilgilerinde uzun gövde metninden ayrılması amacıyla kullanılmıştır. Diğer yandan, iç sayfalarda sıkışık bir espas ilişkisi yaratan gotik yazı aynı zamanda satır düzleminde de sıkı- şık bir boşlukla dizilmiştir. Hiyerarşik olarak algılamayı sağlayan punto farklılıkları, font farklılıkları veya başlık harfleri (Orj. Initials) halen günümüzde de kullanılmakla birlikte, sayfa tasarımında boşluğun kullanımının büyük oranda değiştiğini gözlemlemek mümkündür. Günümüz süreli yayınlarındaki geniş espas kullanımı daha aydınlık sayfalara bakmamızı sağlamıştır. Söz konusu tasarım farklılıklarının okuma edimine dair farklı bir algı biçimini yansıttığını ve değişen görsel kültürümüzün bir uzantısı olduğunu eklemekte fayda vardır.

İngiltere'nin resmi gazetesi olan ve 1665 yllından itibaren kesintisiz yayınlanan en eski gazete olma özelliğini taşıyan "London Gazette" ise bu kullanımın tam tersine çevrildiği bir örnek olmuştur. Bu gazetede, gazetenin adında, büyük başlık harflerinde ve uzun metin bloklarında tırnaklı yazı karakterlerinin ön plana geçmiş olması dikkat çekicidir. Gotik yazı sadece "Published By Authority" ibaresinde kullanılmıştır. Diğer yandan ilk örneklerinde bir arma/ sembol içermeyen London Gazette'ye, ilerleyen süreçlerde kimliğin belirleyici bir parçası olarak kraliyet armasının da eklendiğini görürüz (Resim 4, 5, 6). London Gazetténin tasarım değeri açısından diğer önemli özelliği ise $30 \mathrm{~cm}$.lik kağıt yüksekliği ile günümüzdeki gazete ölçülerine yakın ölçülerde çıkarılan ilk gazete olmasıdır (Ertuğ, 1970: 45).

17. yüzyılda belirginlik kazanan üç yayın türünden ilki; askeri, siyasi, ekonomik, politik vb. genel haberleri içeren ve gündemi yakalamayı hedefleyen 'gazette' tipi gazeteler olmuştur. Diğer tür ise magazin içerikli eğlence yayınlarıdır. Kültürel içerikli yayınlarda ise anatomiye, doğa bilimlerine, kimya, matematik ve fiziğe dair bilimsel metotlara değinilmiş ve dönemin güncel fikir tartışmalarına yer verilmiştir. Kitaplar hakkında bilgi veren kimi süreli yayınlar bir bibliyografya niteliği taşımıștır. Paris'te 16651671 yılları arasında yayınlanan ve dönemin yükselişteki
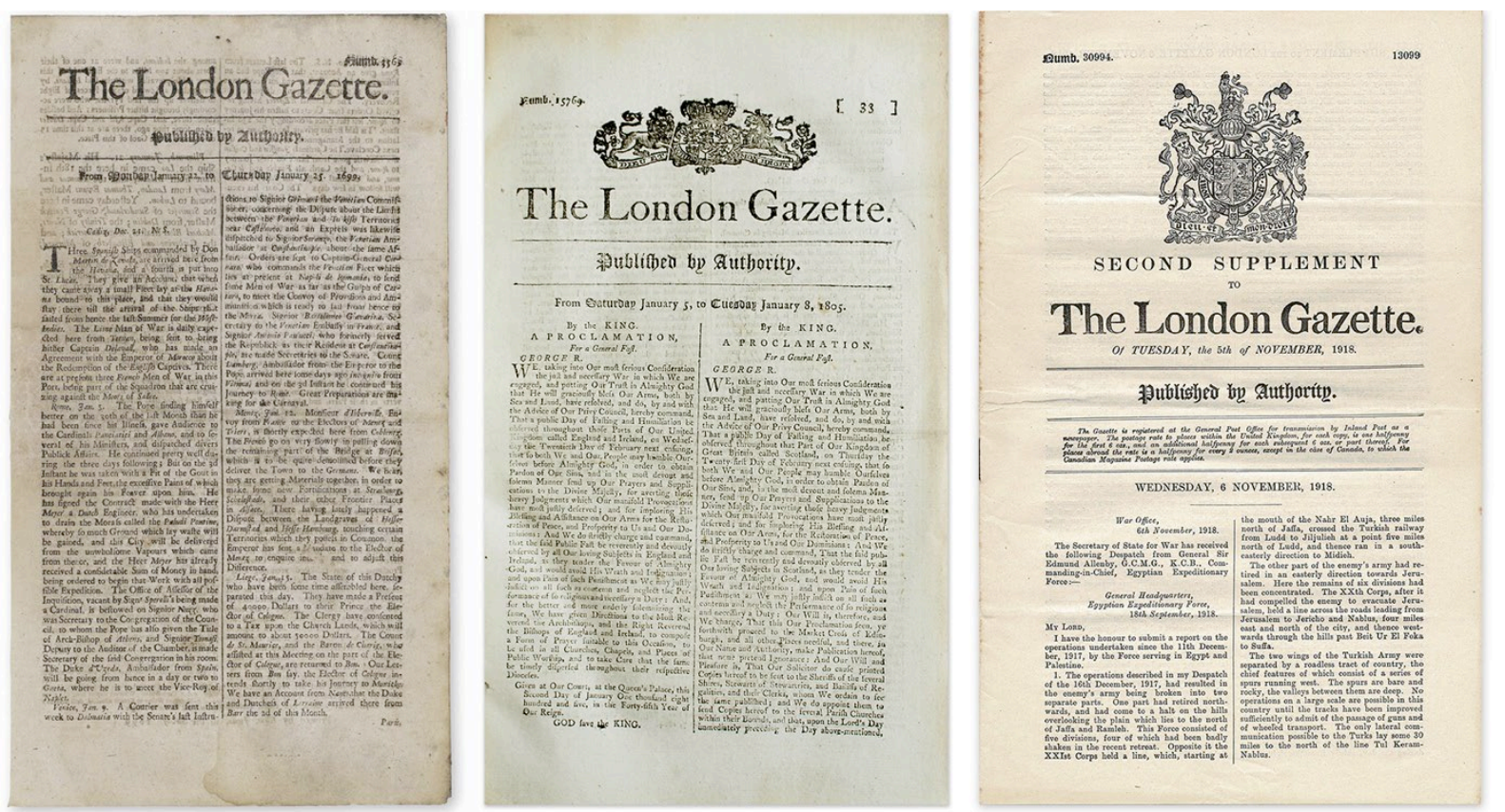

Resim 4, 5, 6: Sırasıyla 1699, 1805 ve 1918 yıllarına ait "London Gazette" nin ilk sayfaları 


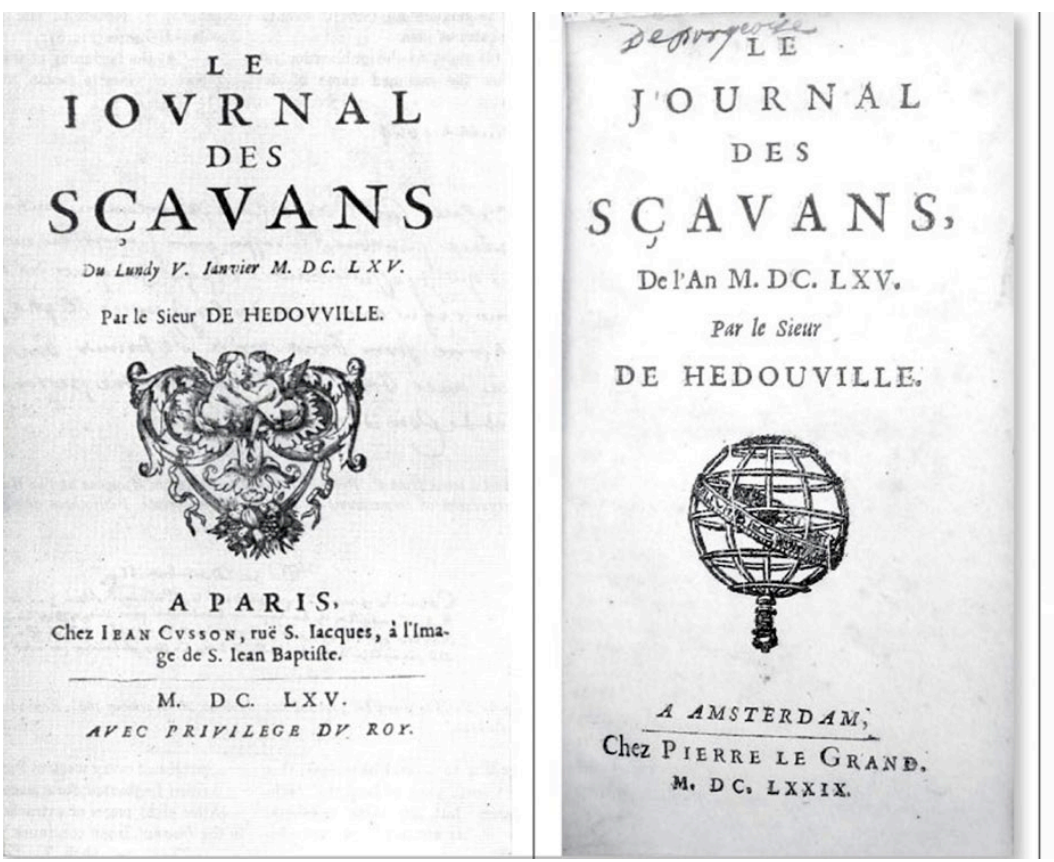

\section{NOU V E A U JOUR NAL D E S SCAVANS, DRESSÉ A BERLIN,} Par Mr. $\mathrm{C} * * *$

PREMIERE ANNE'E.

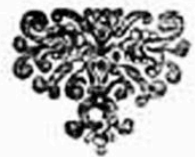

A BERLIN,

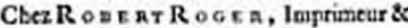

Libraire de S. A. E.

Et $\&$ LEI I S I C,

Chez M. Turodone HeYner. A. $\mathrm{DCC}_{n} \times \mathrm{C} \mathrm{V} \mathrm{l}$.

Resim 7, 8, 9: Paris, Amsterdam ve Berlin'de yayınlanan "Journal Des Savants"ların başlık sayfaları

felsefi düşüncesi olan Dekartçılığı gündeme taşıyan "Journal Des Sçavans”, bu dönemin kültürel içerikli yayınlarına güzel bir örnek teşkil etmiştir. Descartes'in fikirlerine dair tartışmalara, makalelere yer veren bu yayın anlayışı çok kısa bir zamanda Amsterdam, Berlin gibi coğrafyalara, ismiyle olduğu kadar fikirleriyle birlikte de taşınmış; burada makaleler yazan Cordemoy, La Forge, Rohaulti, Desgabets, Regis, Poisson gibi filozoflar sonraki yıllarda kendilerine ait kitaplar da yayınlamışlardır (Dobre, Erişim Tarihi: 04.09.2018, 2012). Bu noktada Descartes'in düşüncelerinin Avrupa coğrafyasına yayılmasında ve kabul görmesinde kitaplara eşlik eden süreli yayınların da etkisinin olduğunu söylemek mümkündür. Bu süreli yayınlar, kitaplarda bulunan metinlerin öncelikli olarak entelektüel çevre arasında tartışılması işlevini görmüş ve devamında kitleleri ilgilendiren bir gündem oluşturmuştur. Diğer yandan farklı şehirlerde yayınlanan bu süreli yayınlarda sayfa düzenlemesinde standart bir kullanımın gerçekleştirilmiş olması dikkat çekicidir. Armalar ve dil değişken olsa bile sayfa düzenlemesindeki boşluk ve hiyerarşi birbirine yakındır. Standartların oluşturulması ve tekrar edilmesi günümüzde yayınlanan süreli yayınların da görsel kimliğinin belirleyici unsurlarıdır.

Süreli yayınların yükselişe geçtiği 17. yüzyılda Fransa'da, gazeteciler ile yazarlar arasında yaşanan gerilim de dikkat çekicidir. Sancılı bir algı dönüşümünün örneği olan bu süreçte Voltaire, Diderot, Roesseau ve Montesquieu gibi öne çıkan Fransız düşünürler, gazeteleri edebiyat eserleri ile kıyaslamış ve gazetecileri yererek, kalıcı olmamalarından ötürü süreli yayınları aşağı görmüşlerdir. Çünkü çoklu yazarların çalışmaları o güne dek bir gazete ya da dergide değil, daha çok Encyclopédie (Ansiklopedi)'lerde bir araya getirilmiştir (Jeanneney, 2006: 48). Bu algının bir uzantısı olarak da basın özgürlüğü kavramı uzun bir süre gazetelerle değil kitaplarla özdeşleştirilmiştir.
17. yüzyılda özel sektörde yaşanan açılımların etkisiyle haberleri kayıt alına alıp, araştıran profesyonel insanlar çoğalmış; çeşitlenen haber bültenlerinde tavernalardan, terzilere dek yeni yeni oluşum gösteren farklı iş kollarına ait reklam niteliğinde anonslara yer verilmeye başlanmıştır (Trentmann, 2012: 242). Tarihte kayıtlara geçmiş 1652 tarihli ilk kahve dükkanı reklamı da dâhil olmak üzere günümüz anlamındaki ilk basın ilanlarına İngiltere öncülük yapmıştır. Bu dönemde İngiltere'deki bir gazetenin ortalama olarak altı reklam aldığı ve bu reklamların çoğunlukla mal ve hizmet reklamları, tiyatro oyunları ya da yarışlar hakkında olduğu bilinmektedir (Briggs, Burke, 2004: 70) İngiltere'de yayınlanan basın ilanlarında dikkati çeken en belirgin özellik, bu reklamların yazı ağırlıklı olmasıdır (Resim 11). Metinlerde farklı punto ölçüleri ve espas ilişkilerinin kullanılmasıyla bir hiyerarşi sağlanmıştır. Resim 11'de, "Royal Theatre" reklamında slogan olarak seçilen "HAMLET" kelimesi ile alt bilgi olarak kullanılan oyun$\mathrm{cu}$, tarih ve yer bilgileri arasındaki kullanım farklılıkları buna güzel bir örnektir. Aynı yüzyılda Fransa'da üretilen reklamlarda ise yazı yerine imgeye ağırlık verilmiş ve iş yeri sahibinin görseline, reklamının yapıldığı iş kolunu, iş yerinin vitrinini betimleyen detaylı illüstrasyonlar eşlik etmiştir. Resim 10'da yer alan 1667 yılına ait "Au Roi Arme”; mutfak gereçleri ve erzak türü yiyecekler satan bir dükkânın reklamı bu kullanıma güzel bir örnektir.

Günlük gazete adına ise İngiltere'de atılan ilk adım 1702 'den 1735 'e dek yayın hayatına devam eden "Daily Courant" olmuştur. Tek sayfadan oluşan bu gazetenin ön yüzünde lokal olduğu kadar deniz aşırı ülkelere dair haberlere yer verilmiştir (Resim 12). Arka yüzü ise tamamen reklamlara ayrılmıştır. Fransa'nın ilk günlük gazetesi "Journal de Paris" ise 1777 tarihinde çıkarılmaya başlanmıştır. Gazetenin 26 Nisan 1784 tarihli baskısının ekonomi bölümünde Benjamin Franklin'in mektubuna anonim bir isimle yer verilmesi dikkati çekmektedir. İngilizce as- 
lından Fransızca'ya çevirilen bu metinde Franklin, ironik bir dille Parislilerin sabah daha erken uyanmak suretiyle daha az mum yakarak paradan ve zamandan tasarruf etmesine dair önerilerde bulunmaktadır (Resim 13).

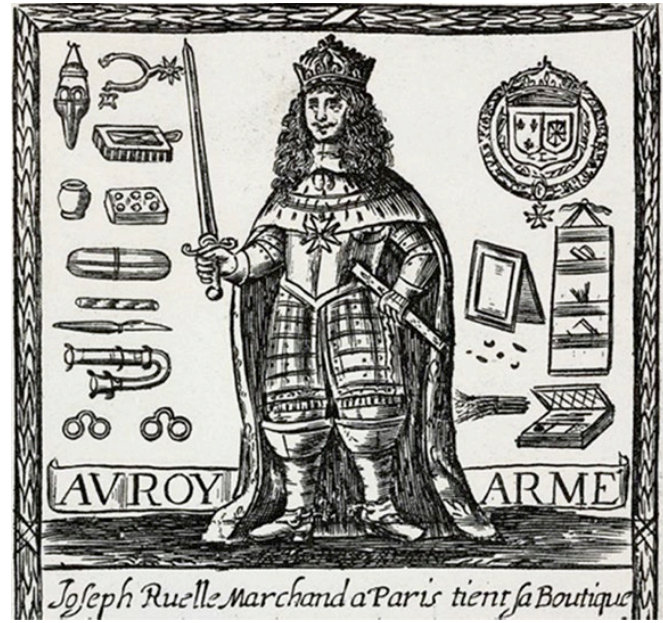

Resim 10: Paris'te yayınlanan bir reklam, 1663

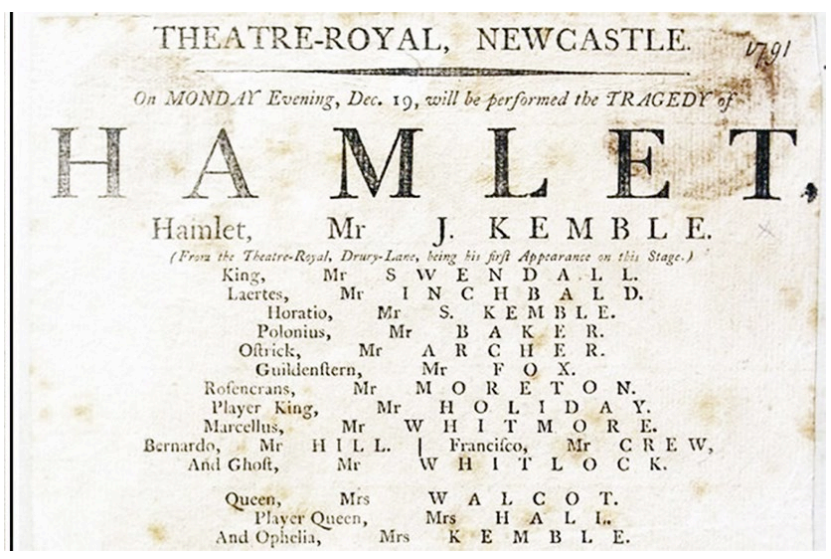

Resim 11: Ingiltere'de yayınlanan bir reklam, 1791

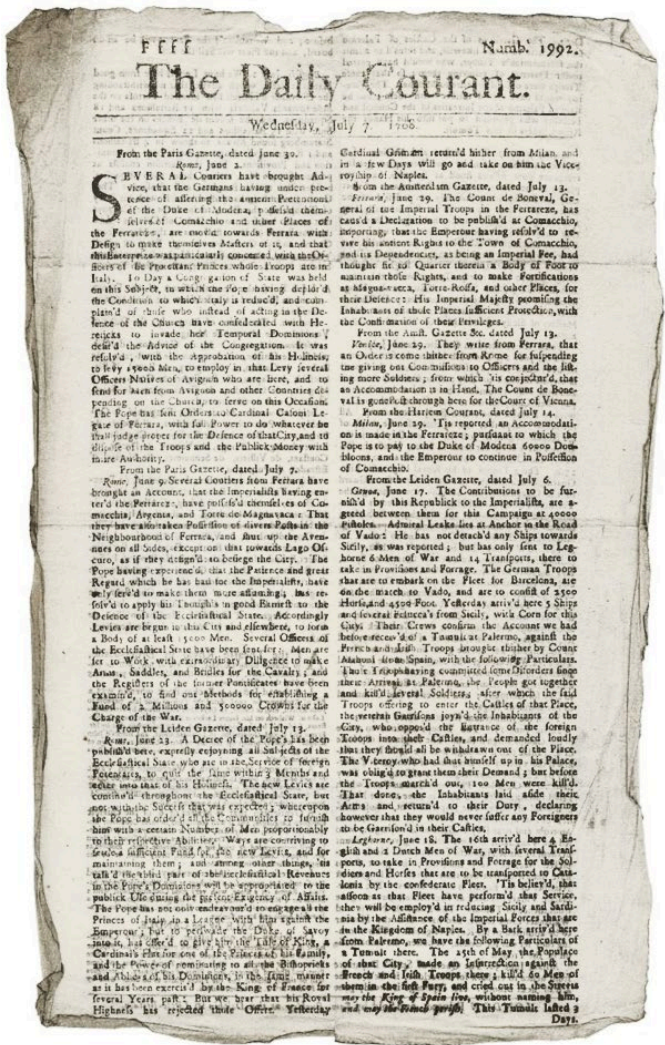

Resim 12: 1708 tarihli "Daily Courant"

$N$ U M E R O II7.

$\$ 21$

\section{JOURNAL DE PARIS.}

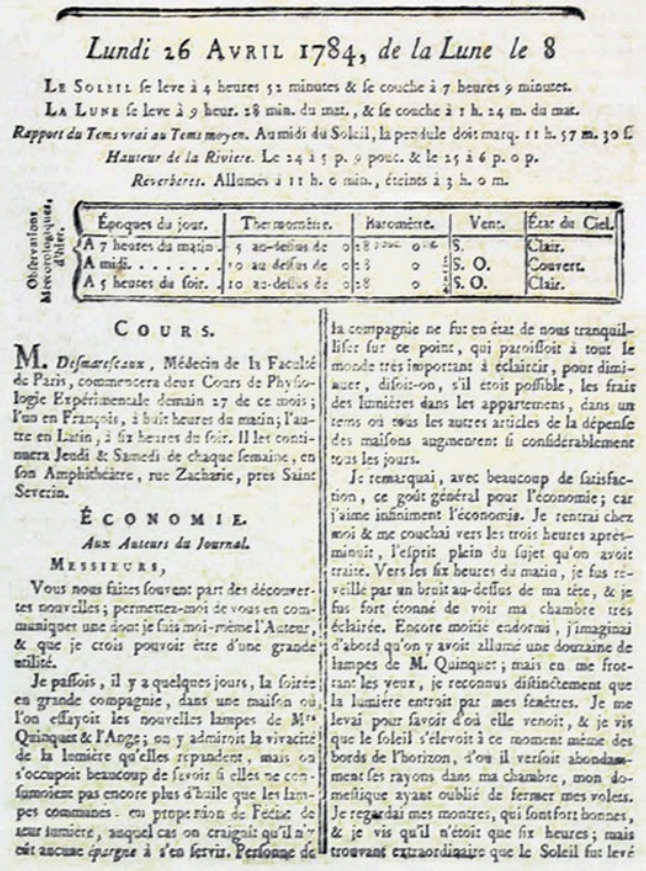

Resim 13: 1784 tarihli "Journal De Paris"

İngiltere'nin o dönemdeki toplumsal yapısına bakıldığında, okur-yazar sayısının diğer Avrupa ülkelerine oranla fazla olması dikkat çekicidir. Londra'da kafe olarak da nitelendirebileceğimiz okuma salonlarının 1690'lı yıllardan beri var olduğu ve yazarların bu gibi yerlerde bir araya gelerek gündemdeki haberleri okuduğu, tartıştığı toplantıların büyük ilgi gördüğü bilinmektedir (Resim 14). Diğer yandan bu dönemde İngiltere'nin, iktidarın sırayla el değiștirdiği tek Avrupa ülkesi olduğunu belirtmekte fayda vardır. Muhalefetteki liberal Whigler ile iktidardaki muhafazakâr Toryler arasında yaşanan sert siyasi çekişme kamuoyunun yoğun ilgisini çekmiştir. Böylesi çekişmeli bir ortamda kendi medyalarını yaratma yolunu seçen muhalefetteki Whig partisi, ifade özgürlüğünü savunmuş ve herkesin serbestçe fikir beyan edebilmesini ön görerek ironik bir yaklaşımla “Tatler” (Tür. geveze) isimli dergiyi çıkarmaya başlamıştır. Tory'ler de 1710 yılında “Examiner" ile karşı yayına geçerek söz konusu tartışmalarını süreli yayınlar üzerinden kamusal alana taşımışlardır. ${ }^{6}$

1700'lü yıllara gelindiğinde halen çoğunluğu okuma-yazma bilmeyenlerden oluşan Fransız toplumunda ise, İngiltere'deki kafe toplantılarının bir benzeri olarak, güncel haberlerin açık alanlarda sözel dille aktarıldığı toplantılar dikkati çekmektedir. Bu toplantılarda kimi zaman gaze-

\footnotetext{
${ }^{6}$ Ingiltere'de 1791 yilında ilk basın kanunu olarak nitelendirilebilecek 'Libel Act' isimli kanunun yürürlüğe girmesi İngiliz basının ilerleyişinde büyük rol oynamıştır. Bu yasayla, yargıcın başkanlık edip / jürinin karar verdiği yargılama sistemine geçilmiştir.
} 
teyi topluluğa yüksek sesle okuyan kişiler yer almış, kimi zaman da yazılı olan ya da olmayan söylenti niteliğindeki haberler paylaşılmıștır. 1740'lı yıllardan itibaren Paris'teki Royal Palace'ın bahçelerinde habercilerin gündemdeki haberleri veya dedikoduları paylaştığı ve hatırı sayılır bir kalabalığın bu haberleri dinlemek üzere bu gibi alanlarda toplandığı bilinmektedir (Resim 15).

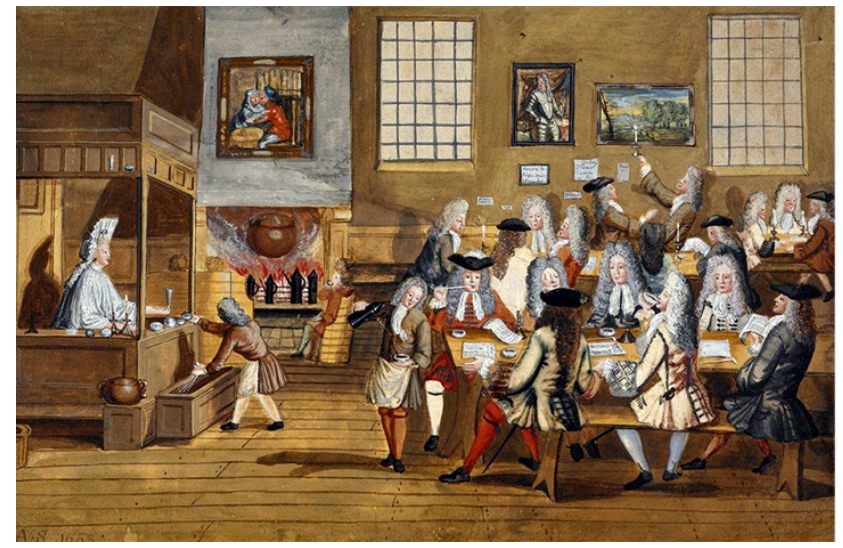

Resim 14: İngiltere'deki kafeden görünüm, 1690-1700

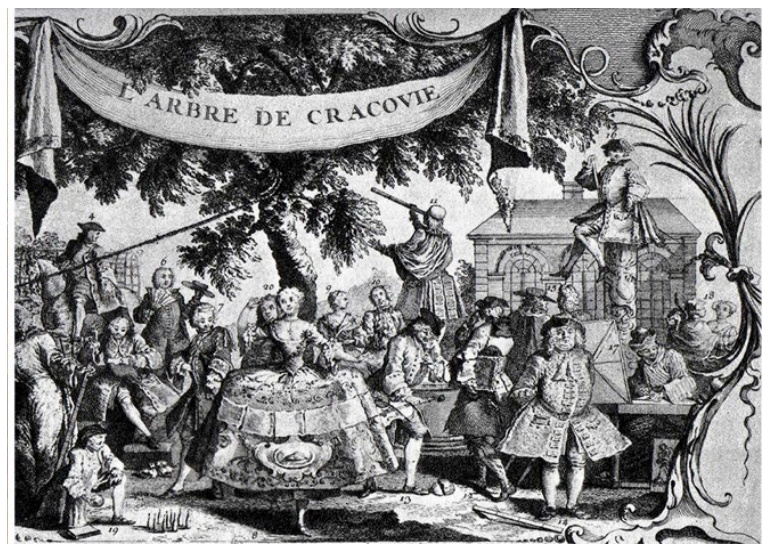

Resim 15: Paris, Royal Palace'tan bir görünüm, 1742

Fransız Devrimi'nin gerçekleştiği 1789'un son altı ayında Fransa'da 250'ye yakın gazete yayınlanmaya başlamış ve bu gazetelerin bazıları günümüz gazete ölçülerinde basılmıştır. Bunun yanı sıra, sansür ve denetimden kurtulmak için yurtdışından kaçak olarak sokulan ya da gizlice üretilen kitaplar da insanlara ulaştırılmıştır. Bu kontrol edilemez bilgi akışı üzerinden satılan yayınlar arasında din karşıtı, politik ve pornografik içerikli yayınlar da yer almıştır (Briggs, Burke, 2004: 118) Pornografik içerikli yayınlarda karakter olarak soylu ailelerin seçilmiş ve kraliyet yaşantısı çarpık ya da sansasyonel bir anlatımla sunulmuştur. Devrim düşüncesinin beslenmesinde ve kamusal alanın oluşmasında bu süreli yayınlar da etkili olmuştur. Dönemin dergilerden biri olan, "Les Révolutions de Paris" in bir sayısında yer alan cümle süreli yayınların etkisini özetler niteliktedir: "Büyükler bize sadece biz diz çökmüş olduğumuz için büyük görünürler. Ayağa kalkalım!”(Jeanneney, 2006: 58)

\section{SONUÇ VE DEĞERLENDIRME}

Süreli yayınların kitleleri etkisi altına alma gücü matbaa tekniğinin gelişiminden bağımsız olarak çok daha ön- ceden keşfedilmiş bir değerdir. Eski Mısır gibi yazının bulunduğu ilk uygarlıklarda bile "yalan haber"lerin kullanılmış olması buna işarettir. Diğer yandan matbaa tekniğinin süreli yayınların doğuşunda olduğu kadar, günümüzde sahip olduğu işlevi ve görsel kimliği kazanmasında etkisinin büyük olduğunu görmek mümkündür. Nitekim çoğu dilde basın terimi matbaadan ileri gelmektedir. (İngilizcede: “the press”, Fransizca'da "la presse”, Almancada "die presse", İtalyancada "la stampa", Türkçe’de "matbuat-basin").

Süreli yayınların doğuş sürecine tasarım değerleri açısından bakıldığında, bu yayınların tipografi tarihindeki dönüşümün ve toplamında basılı metne dair yeni bir görsel kültürün oluşumunun izlerini taşıdığını söylemek mümkündür. Cavalier'e göre bu süreç, özellikle eldeki gerecin ussallaştırılması, başka bir deyişle tasarım kriterlerinin geliştirilmesi olarak yaşanmıştır (Cavalier, 2004: 25). Matbaa tekniği ile üretilen süreli yayınlar, hem içerik hem de görsellik bağlamında kitap tasarımlarından ayrışarak kendi kimliklerini oluşturmaya başlamıştır. İçeriğin ve yayınlanma sıklığının beraberinde; dizgi, sayfa düzeni, boşluğun kullanımı ve boyuta dair değişiklikler bu farklılaşma sürecindeki önemli etkenlerdir.

Matbaanın süreli yayınların bilginin tekelleşmiş güç odaklarının kontrolünden çıkmasını, çeşitlenmesini ve kitlesel olarak paylaşılarak kamusallaşmasını sağlamış olması demokratikleşme tarihi açısından önemlidir. Süreli yayınların gelişiminde iktidarların yasaklama ve cezaları, sansürcü tavirları henüz olgunlaşmamış el yazması haberlerin olduğu dönemde bile en vahşi haliyle boy göstermiştir. 1546'da Lyonlu basımcı Etiene Dolet'in engizisyon mahkemesi kararıyla Paris meydanında yakılarak öldürülmesi bu baskıcı tavrın ne kadar geriye dayandığının bir işaretidir (Törenli, 2005: 51) Günümüzde önemli yazarlar olarak anılan Voltaire, Diderot, Roesseau ve Montesquieu gibi isimlerin muhafazakâr bir tavırla, yaşadıkları dönem içerisinde süreli yayınları değersizleştirme çabaları da bu kabul sürecinin bir parçasıdır.

Araştırmadan 17. ve 18. yüzyılda yaşanan gelişmelerin süreli yayınların tarihi açısından önemli dönemler olduğu sonucu çıkmaktadır. Bu dönemde yazılı basın / basın özgürlüğü gibi kavramlar tartışılmaya ve diğer yandan kamusal alan bilinci yerleşmeye başlamıştır. 1789 Fransız Devrimi sırasında edebiyat ve düşünce yayınları alanında yaşanan gelişmeler kitlelerin okuma pratiklerini de etkilemiştir. Süreli yayınlar toplumların yazı yoluyla kültürleşme dünyasına girişinde, hem de geniş ölçekli okuma pratiklerinin hızlı bir şekilde yayılımında etkili olmuştur (Barbier, Lavenir, 2001: 65) Kitle iletişim araçları yoluyla oluşan bu toplumsal iklim, kamusal alanın varlığının temelinde de rol oynamıştır. Катиоуu teriminin bu dönemde kullanılmaya başlanması, süreli yayınların kitlesel bir iletişim aracı olarak taşıdığı önemin belirgin bir ifadesidir. 1789 sonrası başladığı kabul edilen Yeni Çağ'da (bir çok şeyin olduğu gibi) süreli yayınların varoluş şeklinin 
belirleyicisi 'endüstrileşme' olmuş; bu kırılma noktasından sonra basım alanı bir sektör; basılı yayınlar ise etkili bir kitle iletişim aracı olma yolunda ilerlemiştir.

\section{KISALTMALAR:}

Tür. = Türkçe, Orj. $=$ Orijinal , İng= İngilizce

\section{KAYNAKÇA}

Barbier, Frederic. , Lavenir, Catherine B. (2001). Diderot'dan İnternete Medya Tarihi, İstanbul: Okuyanus Yayın

Briggs, Asa., Burke, Peter. (2004). Medyanın Toplumsal Tarihi, İstanbul: İzdüşüm Yayınları

Brownlees, Nicholas. (2011). The Language of Periodical News in Seventeenth-Century England, UK:Cambridge Scholars Publishing

Burger, Peter. (2007) Charles Fenerty and His Paper Invention, Canada: PB Publishing

Cavalier, Jean Jaques. (2004). Medya ve İletişim Teknolojileri, İstanbul: Salyangoz Yayınları

Dobre, Mihnea. (15.03.2012) "Early Cartesianism and the Journal des Sçavans, 1665-1671", http://doi.org/10.18352/studium.1557, (Erişim Tarihi: 04.07.2018)

Deibert, Ronald. (1997). Parchment, Printing, and Hypermedia, USA:Columbia University Press

Ertuğ, Hasan Refik. (1970). Basın ve Yayın Hareketleri Tarihi, İstanbul Üniversitesi İktisat Fakültesi

Emden, Christian., Midgley, David R. (edt.). (2002). Cultural Memory and Historical Consciousness in the

German- Speaking World, GB:Cambridge University Press

Ham, Ken. (edt.) (2011) The New Answers Book -Volume 2, USA: Master Books

Jeanneney, Jean Noel. (2006). Başlangıcından Günümüze Medya Tarihi, İstanbul: YKY

Martin, Ronald H. (1981). Tacitus, USA: University of California Press

Murphy, Libby. (2016). The Art of Survival: France and the Great War Picaresque, USA: Yale University Press

Törenli, Nurcan. (2005). Yeni Medya, Yeni Illetişim Ortamı, Ankara: Bilim ve Sanat Yayınları

Trentmann, Frank (edt.). (2012). The Oxford Handbook of the History of Consumption, New York: Oxford University Press

Wilke, Jürgen. (14.04.2018) "The Development of Media Genres from the Early Modern to Modern Worlds", http:// brewminate.com/the-development-of-media-genres-from-the-early-modern-to-modern-worlds/ , (Erişim Tarihi: 10.07.2018)

Wright, Denis. (2016). The English Amongst the Persians: Imperial Lives in Nineteenth-Century Iran, London: I.B. Tauris \& Co Ltd.

\section{RESIM KAYNAKÇASI:}

Resim 1: “Relation” başlık sayfası, 1609 https://en.wikipedia.org/ wiki/List_of_the_oldest_newspapers\#/media/File:Relation_Aller_Fuernemmen_und_gedenckwuerdigen_Histo- rien_(1609).jpg (Erişim Tarihi: 10.08.2018)

Resim 2: "Avisa" başlık sayfası, 1609 https://en.wikipedia.org/ wiki/List_of_the_oldest_newspapers\#/media/File:Aviso_ Nr.1_Januar_1609.jpg (Erişim Tarihi: 15.08.2018)

Resim 3: “Nieuwe Tydinghen”, iç sayfa, 1644

http://www.flandrica.be/flandrica/items/show/944 (Erişim Tarihi: 15.08.2018)

Resim 4: 1699 yılına ait "London Gazette"

https://www.harropianbooks.com/pages/books/2887/ general-sir-edmund-h-h-allenby-partialy-drawn-from-some-of-t-e-lawrences-activities/second-supplement-tothe-london-gazette-of-tuesday-the-5th-of-november1918-no-30994-t-e-lawrence (Erişim Tarihi: 03.09.2018)

Resim 5 : 1805 yılına ait "London Gazette"

https://www.traffordbooks.co.uk/lot/the-london-gazette-for-the-year-1805-bound-volume-small-folio-full-buckram-gilt-leather-title/5825 (Erişim Tarihi: 05.08.2018)

Resim 6: 1918 yılına ait "London Gazette"

https://www.mullocksauctions.co.uk/lot-714028-Iondon_ gazette_1678_no1345_dutch.html?p=66 (Erişim Tarihi: 05.09.2018)

Resim 7, 8: Paris ve Amsterdam'da yayınlanan “Journal Des Savants"ların başlık sayfaları

https://www.gewina-studium.nl/articles/10.18352/studium.1557/ (Erişim Tarihi: 12.08.2018)

Resim 9: Berlin'de yayınlanan “Journal Des Savants”ın başık sayfası https://www.haraldfischerverlag.de/hfv/reihen/DtZS/ chauvin_nouveau_journal.ph (Erişim Tarihi: 05.09.2018)

Resim 10: Paris'te yayınlanan bir reklam, 1663

https://www.gettyimages.ca/detail/illustration/au-roi-arme-kitchenware-and-grocery-store-paris-france-stock-graphic/940033862 (Erişim Tarihi: 22.07.2018)

Resim 11: İngiltere'de yayınlanan bir reklam, 1791

https://rogersbooks.wordpress.com/2016/05/18/hamlet-shakespeare/.jpg (Erişim Tarihi: 22.09.2018)

Resim 12: 1708 Tarihli “ Daily Courant”

http://prensahispanaaz.com/wordpress1/efemerides-the-daily-courant-el-primer-diario-en-la-historia/ (Erişim Tarihi: 22.07.2018)

Resim 13: 1784 tarihli "Journal De Paris"

https://tr.wikipedia.org/wiki/Dosya:Franklin-Benjamin-Journal-de-Paris-1784.jpg (Erişim Tarihi: 20.09.2018)

Resim 14: İngiltere'deki kafeden görünüm, 1690-1700 https:// www.laphamsquarterly.org/communication/art/communication-interior-london-coffeehouse (Erişim Tarihi: 12.09.2018)

Resim 15: Paris, Royal Palace'tan bir görünüm, 1742 https://www.nybooks.com/daily/2017/02/13/the-truehistory-of-fake-news/ (Erişim Tarihi: 12.09.2018) 